\title{
HUBUNGAN DUKUNGAN KELUARGA DENGAN TINGKAT KECEMASAN MENGHADAPI KEMATIAN PASIEN HIV/ AIDS DI RSUD dr ABDUL AZIZ SINGKAWANG
}

\author{
Aulia Rahman ${ }^{1}$, Wahyu Kirana ${ }^{2}$, Rara Anggraini ${ }^{3}$ \\ ${ }^{122}$ STIKes Yarsi Pontianak, ${ }^{3}$ RSJD Sungai Bangkong
}

\begin{abstract}
Aulia Rahman: Program Studi Pendidikan Ners STIKes YARSI Pontianak, Jln Panglima A'im, No. 1 Pontianak Timur, Kota Pontianak, Kalimantan Barat-78232 :

Email : rahmanaulia743@gmail.com
\end{abstract}

\begin{abstract}
Abstrak
Latar Belakang: Human Immunodeiciency Virus (HIV)/ Acquired Immuno Deficiency Syndrome (AIDS) merupakan masalah global yang dialami oleh negara di dunia. Berbagai masalah muncul pada pasien HIV/AIDS diantaranya masalah fisik, psikologis dan sosial. Ketiga masalah tersebut merupakan stresor yang dapat menyebabkan kecemasan. Selain itu, kecemasan dapat muncul dari banyaknya berita tentang kematian pasien ODHA. Kematian orang lain yang mengalami masalah yang sama akan menjadi faktor munculnya kecemasan akan kematian. Tujuan: Penelitian ini bertujuan untuk mengetahui hubungan dukungan keluarga dengan tingkat kecemasan menghadapi kematian pasien ODHA (HIV/AIDS) di RSUD dr. Abdul Aziz Singkawang. Metode Penelitian: Penelitian ini merupakan jenis penelitian kuantitatif dengan desain potong lintang (cross sectional) yang bertujuan untuk mengetahui hubungan antar variabel dukungan keluarga dengan tingkat kecemasan terhadap 30 penderita ODHA di RSUD dr. Abdul Aziz Singkawang. Hasil Penelitian: Hasil analisis data dengan uji Chi-Square ditemukan ada hubungan yang signifikan antara dukungan keluarga dengan tingkat kecemasan menghadapi kematian pasien ODHA dengan nilai $p$-value $=0,048$. Kesimpulan: Kesimpulan dari hasil penelitian ini adalah terdapat hubungan dukungan keluarga dengan tingkat kecemasan menghadapi kematian pasien ODHA di RSUD dr. Abdul Aziz Singkawang.
\end{abstract}

Kata Kunci: Dukungan Keluarga, Kecemasan dan HIV/ AIDS.

\section{Abstract}

Background: Human Immunodeiciency Virus (HIV) / Acquired Immuno Deficiency Syndrome (AIDS) is not only a problem that occurs at the local level, but has become a regional and global problem. Various problems arise in patients with HIV / AIDS including physical, psychological and social problems. These three problems are stressors that can cause anxiety. In addition, anxiety can arise from the many news about the death of PLHIV patients. The death of other people who experience the same problem will be a factor in the emergence of anxiety about death. Purpose: This study aims to determine the relationship of family support with the level of anxiety facing the death of patients (HIVI AIDS) in RSUD dr. Abdul Aziz Singkawang. Methods: This research is a type of quantitative study with a cross sectional design of 30 people with HIV / AIDS in dr. Abdul Aziz Singkawang. Results: Data using the Chi-Square results show that there is a significant relationship between family support and the level of anxiety facing the death of PLWHA patients at RSUD dr. Abdul Aziz Singkawang with p-value $=0.048$. Conclusion: Especially people with HIV / AIDS are expected to be able to continue to carry out positive activities in life, have a close relationship with the surrounding environment, and have a good understanding of themselves so they can find out their weaknesses and strengths.

Keywords: Family Support, Anxiety and HIV/ AIDS 


\section{PENDAHULUAN}

Masalah Human Immunodeiciency Virus (HIV)/ Acquired Immuno Deficiency Syndrome (AIDS) bukan hanya sebagai permasalahan yang terjadi di tingkat lokal, namun sudah menjadi permasalahan regional maupun global. Masalah ini telah menimbulkan banyak korban, baik anakanak maupun orang dewasa. AIDS bukan hanya berdampak secara medis namun juga berdampak secara psikososialspritual. Kondisi ini sangat memprihatinkan apabila tidak ditangani dengan cepat dan tepat (Rahakbauw, 2016: 64).

AIDS merupakan kumpulan tanda gejala penyakit yang disebabkan oleh virus HIV. HIV merupakan virus yang merusak sel-sel immune dalam darah yang juga disebut dengan istilah sel limfosit $T$ helper atau sel limfosit CD4. Sel ini berfungsi sebagai sistem daya tahan tubuh dan kekebalan dalam tubuh seseorang. Jika HIV sudah masuk, ia akan menyatu dengan sel limfosit dan berkembang biak, sehingga dari satu sel limfosit akan melahirkan ribuan HIV turunan. Manusia yang terinfeksi HIV akan mengalami penurunan daya tahan tubuh. Selanjutnya sel-selnya akan menurun secara bertahap, baik secara fungsi (kualitas) maupun jumlah (kuantitas) sebagaimana yang dibutuhkan oleh tubuh manusia normal. Pada akhirnya, tidak hanya kekebalan imunitas yang terganggu, tetapi juga kekebalan humoral. Jika sudah demikian, akan mudah sekali terjadi infeksi oportunistik (Madyan, 2009: 40).

United Nations Programme on HIV/AIDS (UNAIDS), menyatakan bahwa pada tahun 2017 diperkirakan 3,4 juta orang (semua umur) terinfeksi HIV. HIV juga membunuh hampir 1 juta orang setiap tahun di seluruh dunia (UNAIDS, 2018: 6). Prevalensi HIV di Indonesia juga berada pada kondisi yang memprihatinkan. Berdasarkan laporan perkembangan HIVAIDS \& Infeksi Menular Seksual (IMS) pada bulan Januari - Maret 2017 jumlah penderita yang terinfeksi HIV sebanyak 10.376 orang dan AIDS berjumlah 673 orang, pada bulan Oktober - Desember 2017 menjadi 14.640 orang terinfeksi HIV dan AIDS 4.725 orang (Kemenkes RI, 2018: 1). Sedangkan untuk lingkup provinsi Kalimantan Barat prevalensi kasus HIV pada tahun 2017 berjumlah 601 kasus, AIDS berjumlah 531 kasus, dengan jumlah kematian akibat AIDS sebanyak 299 orang (DinKes Provinsi Kalimantan Barat, 2017: 2).

Hingga saat ini, penularan HIV hanya bisa terjadi jika ada kontak darah antara orang yang terinfeksi dan orang yang masih sehat. HIV menular lewat cairan semen (cairan yang menyertai sperma), cairan-cairan vaginal, kontak darah atau proses transplantasi organ dari orang yang telah terinfeksi HIV (Rahakbauw, 2016: 1). Menurut Murni, dkk (2015: 2) umumnya seseorang yang tertular virus HIV pada awalnya tidak menunjukkan gejala. Kurang lebih 2-3 minggu setelah tertular, beberapa orang mengalami gejala mirip flu; demam, sakit kepala, otot dan sendi yang sakit, sakit perut, kelenjar getah bening yang bengkak atau ruam pada kulit selama satu atau dua minggu. Gejala ini biasanya hilang tanpa diobati. Virus akan menggandakan diri dalam tubuh untuk beberapa minggu atau bahkan bulan sebelum sistem kekebalan menanggapinya. HIV terus merusak sistem kekebalan tubuh seseorang hingga dengan waktu yang lama akan mengakibatkan AIDS. 
Berbagai masalah muncul pada pasien HIV/AIDS diantaranya masalah fisik dan psikologis. Secara fisik penderita HIV/AIDS akan mengalami penurunan berat badan, ruam kulit, kelelahan kronis, nyeri otot dan sendi. ODHA juga menghadapi masalah social, yaitu sering menerima perlakuan tidak adil, stigma dan diskriminasi yang cukup memprihatinkan dari lingkungan keluarga dan masyarakat. Tindakan diskriminasi yang didapatkan ODHA seperti pengucilan, tidak mau berjabatan tangan atau melakukan kontak dengan ODHA. Demikian pula dengan stigma yang diberikan kepada ODHA sebagai sampah masyarakat. Masalah psikologis yang umum terjadi yaitu; mudah lupa, sukar mengendalikan dorongan seksual, cemas atau khawatir menhadapi sesuatu yang baru (Rachmawati, 2013: 1).

Semua ODHA setelah pertama mendengar bahwa mereka positif HIV yaitu mereka merasakan tidak bersemangat untuk bekerja, tidak dapat bergaul, tidak ada nafsu makan, depresi berkepanjangan dan yang paling parah adalah tidak bersemangat untuk melanjutkan hidup. Saat ODHA mengalami kondisi sakit ringan hingga parah mereka merasakan kondisi stres berat dengan status ODHA yang harus mereka tanggung seumur hidup (Hermawan, 2009: 11). Individu yang positif terinfeksi HIV, menjalani kehidupannya akan terasa sulit karena dari segi fisik individu tersebut akan mengalami perubahan yang berkaitan dengan perkembangan penyakitnya, tekanan emosional dan stres psikologis yang dialami karena dikucilkan oleh keluarga dan teman karena takut tertular, serta adanya stigma sosial dan diskriminasi di masyarakat. Larasaty dkk (2015:118) dalam penelitinya menemukan hal yang berdampak pada respons sosial (emosional) pasien, sebagai contoh adanya stigma sosial yang dapat menyebabkan gangguan perilaku pada orang lain, termasuk menghindari kontak fisik dan sosial. Mereka menjalani kehidupannya dalam kekhawatiran dan stres.

Masalah fisik, psikologis dan sosisal yang dialami pasien HIV/ AIDS merupakan stresor yang dapat menyebabkan kecemasan. Kondisi fisik menurun dapat berpengaruh pada suasana hati, dan aktivitas lain. Hal ini sesuai dengan penelitian yang dilakukan oleh Chusna dan Nurhalina (2019: 99) yang mengemukakan bahwa terkait dengan state anxiety pada ODHA cenderung tidak stabil dan ketika ada kondisi tertentu dapat meningkatkan kecemasan.

Selain diakibatkan masalah fisik, kecemasan dapat muncul dari banyaknya berita tentang kematian pasien ODHA. Kematian orang lain yang mengalami masalah yang sama akan menjadi faktor munculnya kecemasan akan kematian (Siregar \& Hardjo, 2017: 27). Hal senanda dikemukan oleh Hurlock (1996 dalam Siregar \& Hardjo, 2017: 28) bahwa kecemasan dapat berkaitan dengan datangnya kematian dan dapat juga berkaitan dengan caranya kematian serta rasa sakit atau siksaan yang menungkin menyertai datangnya kematian. Kecemasan kematian bisa menyerang siapa saja, umumnya kecemasan kematian merupakan suatu pikiran yang tidak menyenangkan, yang ditandai dengan kekhawatiran, rasa tidak tenang dan perasaan yang tidak baik atau tidak enak yang tidak dapat dihindari oleh seseorang.

Ahdiany dkk (2017: 200) menyatakan bahwa terdapat perbedaan 
antara kecemasan secara umum dengan kecemasan terhadap kematian, yaitu objek dari rasa ketidaknyamanan tersebut dan dampak yang ditimbulkan. Kecemasan terhadap kematian adalah kondisi individu yang tidak menyenangkan meliputi gelisah, sulit tidur, bingung, was-was dan tidak nyaman akibat objek yang tidak jelas atau bahkan belum terjadi berupa peristiwa saat terlepas jiwa dan raga. Setiadarma dan Zamarlita (2008 dalam Ahdiany, 2017: 201) menyatakan bahwa kecemasan terhadap kematian muncul pada penderita penyakit kronis seiring dengan semakin melemahnya kondisi fisik, sosial dan psikologis penderta. Kecemasan terhadap kematian yang dirasakan ODHA membuat ODHA menjadi sangat sensitif seperti gemetar, panas dingin bahkan sampai kehilangan kesadaran, jika mendengar atau melihat berita tentang bencana, berita berduka dari kerabat ataupun hal-hal yang mendekati kematian.

Kecemasan menghadapi penyakit atau kecemasan menghadapi kematian pada pasien ODHA dipengaruhi banyak hal. Salah satu faktor yang diduga berpengaruh terhadap kecemasan adalah dukungan keluarga. Dukungan keluarga sangat dibutuhkan oleh ODHA sebagai sistem pendukung utama sehingga dapat mengembangkan respon koping yang efektif untuk beradaptasi dengan baik dalam menangani stressor yang dihadapi terkait penyakitnya baik fisik, psikologis maupun sosial (Kusuma, 2011). Menurut Fredman (1997, dalam Muhith \& Siyoto, 2016: 121), dukungan keluarga adalah sikap, tindakan dan penerimaan keluarga dengan penderita yang sakit. Keluarga berfungsi sebagai sistem pendukung bagi anggotanya dan anggota keluarga memandang bahwa orang yang bersifat mendukung, selalu siap memberikan pertolongan dan bantuan jika diperlukan.

Menurut Witty et al (1994, dalam Larasaty dkk, 2015: 122) menyatakan bahwa salah satu bentuk dukungan keluarga dalam upaya mengurangi kecemasan pasien ODHA yaitu orang tua atau keluarga berusaha menghibur dan memberi nasehat kepada pasien supaya tidak membebani diri dengan penyakit yang diderita. Keluarga perlu memahami fungsi pemeliharaan kesehatan, meliputi mengenal masalah kesehatan keluarga, memutuskan tindakan kesehatan yang tetap bagi keluarga, merawat keluarga yang mengalami gangguan kesehatan (salah satunya mengantar keluarga kunjungan/ kontrol ke fasilitas kesehatan), memodifikasi lingkungan keluarga dan memanfaatkan fasilitas kesehatan disekitarnya bagi keluarga.

Penelitian oleh Yasmin (2017: 461) mendapatkan hasil bahwa ada hubungan negatif antara dukungan keluarga dengan kecemasan pada remaja HIV/ AIDS, artinya arah hubungan berlawanan sehingga semakin tinggi dukungan keluarga maka semakin rendah kecemasan remaja HIV/ AIDS. Ahdiany, dkk (2017: 206) menyatakan beberapa sumber penyebab kecemasan terhadap kematian yaitu pasien mencemaskan kematian mereka dan keluarga yang ditinggalkan juga merasakan cemas akan kematian anggota keluarganya yang sakit. Terlepas dari hal tersebut, kematian merupakan suatu proses yang hakiki yang akan dilewati oleh setiap orang, tidak mengenal usia, jenis kelamin, kondisi fisik ataupun latar belakangnya dan kematian itu sendiri akan datang pada waktu yang tidak kita ketahui. 
Berdasarkan hasil studi pendahuluan yang dilakukan peneliti pada tanggal pada tanggal 11 Mei 2019, didapat data dari RSUD dr Abdul Azis Singkawang pada tahun 2018 penderita ODHA yang berobat berjumlah 1.957 orang yang terdiri dari 1.324 laki-laki dan perempuan 633 orang. Dari jumlah tersebut, 1.683 orang heteroseksual, 76 orang homoseksual, 120 orang pecandu dan 78 orang balita. Selain itu, peneliti melakukan wawancara pada pederita ODHA yang berkunjung di RSUD dr Abdul Aziz sebanyak 3 pasien ODHA, didapatkan bahwa 2 pasien ODHA mengatakan mengalami gejala-gejala cemas terhadap penyakit yang dideritanya, pasien merasakan tidak nyaman, gelisah sulit untuk tidur. Selain itu, pasien mengeluh terhadap kondisi keluarga yang merawatnya selama ini, mereka khawatir suatu saat akan meninggalkan keluarga dikarenakan kondisi penyakit yang dideritanya. Satu pasien ODHA merasa hancur setelah didiagnosa HIV/ AIDS berdampak pada aktivitas sosial dan mereka merasa terkucilkan.

\section{METODE}

Penelitian ini merupakan jenis penelitian kuantitatif dengan desain potong lintang (cross sectional). Desain cross sectional adalah desain penelitian analitik yang bertujuan untuk mengetahui hubungan antar variabel dimana variabel independen dan variabel dependen diidentifikasi pada satu satuan waktu (Dharma, 2011: 79). Teknik sampel penelitian yang digunakan adalah teknik purposive sampling yaitu sampel yang diambil sesuai dengan kriteria atau ciri-ciri khusus yang sesuai dengan tujuan penelitian (Sarwono, 2010: 36).
Penelitian ini telah lolos uji etik penelitian dengan nomor : 113/BAAK/STIKes.YSI/VII/2019.

\section{HASIL}

Hasil penelitian didapatkan 30 responden yang terlibat dalam penelitian ini. Hasil analisis univariat menggambarkan karakteristik responden berdasarkan jenis kelamin, usia, pekerjaan,, status perkawinan, lamanya menderita HIV/ AIDS, dukungan keluarga dan tingkat kecemasan di RSUD dr. Abdul Aziz Singkawang.

Tabel 1. Distribusi frekuensi penderita ODHA berdasarkan karakteristik di RSUD dr. Abdul Aziz Singkawang pada bulan

\begin{tabular}{ccc}
\multicolumn{3}{c}{ Juli $2019(\mathrm{~N}=30)$} \\
\hline Kategori $\quad$ Jumlah & $\begin{array}{c}\text { Prosentase } \\
(\%)\end{array}$
\end{tabular}

Jenis kelamin
a. Laki-laki
18
60,0
b. Perempuan
12
40,0

Status Pekerjaan:

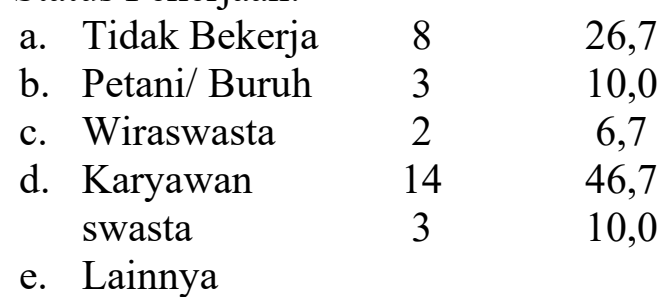

Status perkawinan

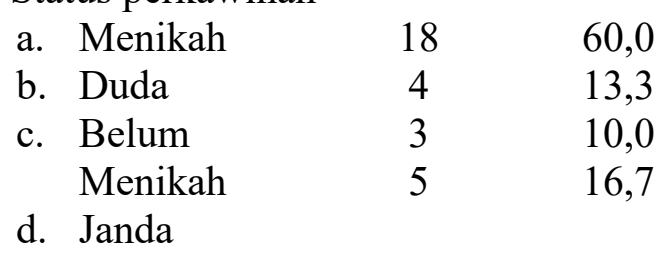

Berdasarkan Tabel 1, menunjukkan bahwa dari 30 responden penderita ODHA sebagian besar yang berjenis kelamin lakilaki 18 orang $(60,0 \%)$, sebagian besar status pekerjaan karyawan swasta 14 orang $(46,7 \%)$ dan sebagian besar status perkawinan responden menikah 18 orang $(60 \%)$. 
Tabel 2. Distribusi Karakteristik

Responden Berdasarkan Usia dan

Lamanya Menderita ODHA ( $=30)$

\begin{tabular}{|c|c|c|c|c|c|}
\hline Variabel & $\mathrm{N}$ & $\begin{array}{c}\mathrm{Mi} \\
\mathrm{n}\end{array}$ & $\begin{array}{c}\mathrm{Ma} \\
\mathrm{x}\end{array}$ & $\begin{array}{c}\text { Mea } \\
\mathrm{n}\end{array}$ & SD \\
\hline \multirow[t]{3}{*}{$\begin{array}{c}\text { Dukungan } \\
\text { Keluarga }\end{array}$} & \multicolumn{3}{|c|}{$\begin{array}{c}\text { Tingkat } \\
\text { Kecemasan }\end{array}$} & \multirow[t]{2}{*}{ Total } & \multirow[t]{3}{*}{$\begin{array}{c}\mathrm{P} \\
\text { Value }\end{array}$} \\
\hline & & Iggi & Rendah & & \\
\hline & $\begin{array}{l}{ }^{n} \\
\%\end{array}$ & & $\begin{array}{l}n \\
\%\end{array}$ & $\underbrace{n}_{0}$ & \\
\hline Baik & $\begin{array}{r}7 \\
58\end{array}$ & & $\begin{array}{c}5 \\
41,7\end{array}$ & $\begin{array}{r}12 \\
100\end{array}$ & 0,048 \\
\hline
\end{tabular}

Buruk

\begin{tabular}{cccc|c|c|}
\multicolumn{1}{c}{} & 3 & 15 & 18 \\
\multicolumn{1}{c}{16,7} & 83,3 & 100 & \\
\hline Jumlah & 10 & 20 & 30 & \\
& \multicolumn{2}{c}{33,3} & 66,7 & 100 \\
\hline Usia & 3 & 22 & 50 & 35,2 & 6,41 \\
& 0 & & & 7 & 1 \\
\hline Lamanya & 3 & 2 & 13 & 7,37 & 2,83 \\
Menderit & 0 & & & & 4 \\
a ODHA & & & & & \\
\hline
\end{tabular}

Berdasarkan table 2, dapat dilihat bahwa responden penderita ODHA rata-rata berusia 35,27 tahun dan lamanya menderita ODHA rata-rata 7,37 tahun.

Tabel 3. Karakteristik responden berdasarkan dukungan keluarga $(\mathrm{N}=30)$ Penderita ODHA di RSUD dr. Abdul Aziz Singkawang Juli 2019

\begin{tabular}{lcc}
\hline \multicolumn{1}{c}{ Kategori } & Jumlah & Prosentase (\%) \\
\hline Dukungan & & \\
keluarga: & 12 & 40,0 \\
a. Baik & 18 & 60,0 \\
b. Buruk & & \\
\hline
\end{tabular}

Tabel 3, menunjukkan bahwa sebagian besar responden yang memiliki dukungan keluarga yang buruk sebanyak 18 orang $(60,0 \%)$ dan sebagian lainnya memiliki dukungan keluarga yang baik 12 orang $(40,0 \%)$.
Tabel 4. Karakteristik responden

berdasarkan tingkat kecemasan $(\mathrm{N}=30)$

Penderita ODHA di RSUD dr. Abdul Aziz Singkawang Juli 2019

\begin{tabular}{lcc}
\hline \multicolumn{1}{c}{ Kategori } & Jumlah & Prosentase (\%) \\
\hline Tingkat & & \\
Kecemasan: & 10 & 33,3 \\
a. Tinggi & 20 & 66,7 \\
b. Rendah & & \\
\hline
\end{tabular}

Tabel 4, menunjukkan bahwa sebagian responden yang memiliki tingkat kecemasan yang tinggi sebanyak 10 orang $(33,3 \%)$ dan sebagian lainnya memiliki tingkat kecemasan yang rendah 20 orang $(66,7 \%)$.

Tabel 5 Rata-rata dukungan keluarga dengan tingkat kecemasan

$(\mathrm{N}=30)$ Penderita ODHA di RSUD dr. Abdul Aziz Singkawang Juli 2019

Berdasarkan tabel 5, didapatkan bahwa dukungan keluarga yang baik sebanyak 7 orang $(58,3 \%)$ memiliki tingkat kecemasan yang tinggi di RSUD dr. Abdul Aziz Singkawang, sedangkan dukungan keluarga yang buruk memiliki tingkat kecemasan yang rendah 15 orang $(83,3 \%)$. Hasil analisis didapatkan nilai $p$-value $=$ 0,048 artinya ada hubungan dukungan keluarga dengan tingkat kecemasan menghadapi kematian pasien ODHA di RSUD dr. Abdul Aziz Singkawang.

\section{PEMBAHASAN}

1. Usia

Berdasarkan hasil penelitian didapatkan bahwa penderita ODHA rata-rata berusia 35,27 tahun. Menurut Birren dan Jenner (1997 dalam Efendi \& Makhfudli, 2009: 244) mengusulkan untuk membedakan usia biologis, usia psikologis dan usia sosial. Usia biologis adalah usia yang 
menunjuk pada jangka waktu seseorang sejak lahirnya, berada dalam keadaan hidup atau tidak mati. Usia psikologis adalah usia yang menunjuk pada kemampuan seseorang untuk mengadakan penyesuaian-penyesuaian kepada situasi yang dihadapinya. Sedangkan, usia sosial adalah usia yang menunjukkan kepada peranperan yang diharapkan atau diberikan masyarakat kepada seseorang sehubungan dengan usianya. Menurut Kemenkes RI (2014: 2) Pola penularan HIV berdasarkan kelompok dalam 5 tahun terakhir tidak banyak berubah. Infeksi HIV paling banyak terjadi pada kelompok usia produktif 25-49 tahun.

Sejalan dengan hasil penelitian Umam dkk (2015: 856) menunjukkan bahwa orang risiko tinggi HIV dan AIDS mayoritas berumur 17-25 tahun (remaja akhir) yaitu sebanyak 46 orang (54.8\%). Menurut Notoatmodjo (2007 dalam Umam dkk, 2015: 856) usia mempengaruhi daya tangkap dan pola pikir seseorang. Pada usia menuju dewasa, individu akan lebih berperan aktif dalam masyarakat dan kehidupan sosial, selain itu orang usia tersebut akan lebih banyak menggunakan banyak waktu untuk membaca. Kemampuan intelektual, pemecahan masalah dan kemampuan verbal dilaporkan hampir tidak ada penurunan pada usia dini.

Penelitian yang dilakukan oleh Luthfiana (2012) didapatkan bahwa orang risiko tinggi HIV dan AIDS berada dalam kategori umur di bawah 29 tahun. Seiring dengan perkembangan HIV dan AIDS, kelompok tertentu ditemukan lebih rentan memiliki perilaku seksual berisiko terhadap HIV dan AIDS. Kelompok umur remaja merupakan masa krisis dimana pemahaman terhadap perilaku masih belum cukup matang. Walaupun kelompok umur remaja memiliki kemampuan kognitif untuk menentukan perilaku yang sehat, pada prakteknya remaja sering terdorong oleh kekuatan lain yang membuat mereka tidak berperilaku secara sehat.

Peneliti berpendapat bahwa semakin bertambahnya usia rasa ingin tahu seseorang terhadap perilaku seksual semakin meningkat. Pada usia muda rentan dan lebih beresiko berperilaku seksual tidak aman sehingga kurang dalam melakukan tindakan pencegahan penularan HIV dibanding dengan usia tua. Beban psikologis yang dihadapai usia dewasa lebih besar dikarenakan pemikiran masa depan yang masih panjang sehingga pola koping dimasa muda lebih rentan ke arah yang mal adaptif. Remaja mulai tampak bebas ingin mencari identitas diri, adanya keingin ketertarikan pada sejenis, ada perasaan cinta, kemampuan berpikir secara abstrak berkembang berkhayal mengenai hal-hal yang berkaitan dengan seksual. masa ini remaja penuh gejolak, termasuk 
masa interaksi dengan kawan sejenis

\section{Jenis Kelamin}

Berdasarkan hasil penelitian menunjukkan bahwa dari 30 responden penderita ODHA sebagian besar yang berjenis kelamin laki-laki 18 orang $(60,0 \%)$. Menurut Sudarma (2008: 188) menyatakan pengertian jenis kelamin (seks) merupakan pembagian dua jenis kelamin yang ditentukan secara biologis, yaitu bahwa pria memiliki penis (zakar) serta memproduksi sperma, sedangkan wanita memiliki alat reproduksi seperti rahim, payudara (untuk menyusui) secara permanen tidak berubah.

Sejalan dengan hasil penelitian Umam, dkk (2015: 857) menunjukkan bahwa jenis kelamin terbanyak adalah laki-laki sebanya 43 orang $(51.2 \%)$ dan perempuan sebanyak 41 orang (48.8\%). Kerentanan laki-laki terhadap infeksi HIV dan AIDS disebabkan oleh perilaku negatif yang dilakukan seperti membeli jasa seks komersial dan memakai suntik, dan laki-laki mempunyai mobilitas tinggi dan jauh dari pasangan.

Irmaningrum et al (dalam Kambu, 2016: 204) menemukan bahwa frekuensi kontak seksual berganti-ganti pasangan di Papua menunjukkan perbedaan yang signifikan antara laki-laki dan perempuan, yaitu proporsi terbesar dimana pada laki-laki sebesar $28 \%$, sementara proporsi terkecil yaitu pada perempuan sebesar $12 \%$. Tinggi-nya prevalensi kasus HIV/AIDS pada laki-laki lebih dikarenakan oleh perilaku seksual berisiko yang lebih rentan dilakukan laki-laki dibandingkan perempuan. Sejalan dengan hasil laporan Ditjen PP dan PL 92016 dalam Ibrahim dkk, 2017: 275) menyatakan bahwa penderita HIV/AIDS terbanyak ialah lakilaki dan merupakan salah satu faktor resiko tertinggi dalam penularan infeksi HIV/AIDS. Hal ini karena berdasarkan hasil survey yang dilakukan oleh BKKBN didapatkan bahwa seorang pekerja seks wanita yang terinfeksi HIV/AIDS sedikitnya dapat menularkan kepada 6 pria yang melakukan hubungan seks dengannya. Selain itu, hubungan seks sesama jenis juga merupakan salah satu resiko penularan yang tinggi dikalangan sesama pria.

Peneliti berpendapat bahwa jenis kelamin merupakan salah satu faktor terjadinya HIV/ AIDS lebih rentan pada pria dibanding wanita. Secara biologis nafsu pria lebh tinggi dibanding wanita, selain itu pergaulan bebas mendasari pria terjerumus ke perilaku negatif seperti merokok, minmamn keras, konsumsi obat terlarang serta perilaku seks bebas.

\section{Status Pekerjaan}

Berdasarkan hasil menunjukkan bahwa sebagian besar status pekerjaan karyawan swasta 14 orang $(46,7 \%)$. Sejalan dengan hasil laporan oleh Komisi 
Penanggulangan AIDS (KPA) Kota Bandung (2013 dalam Ibrahim dkk, 2017: 275) pekerjaan terbanyak pada pasien HIV AIDS yaitu pada pekerja swasta $(26,65 \%)$, dan wiraswasta (16,75\%). Walaupun demikian, akhir-akhir ini prevalensi HIV pada ibu rumah tangga (IRT) dan kelompok tidak bekerja juga cenderung meningkat. Kasus penularan HIV pada IRT dalam penelitian ini dilaporkan $18.2 \%$ dan sejalan dengan laporan KPA Kota Bandung terkait penularan HIV melalui transmisi seks pada IRT yang saat ini mencapai 11,70 \% dari kasus HIV total.

Ibrahim dkk (2017: 275)

berdasarkan pekerjaan yang mereka lakukan diperoleh penghasilan dimana ratarata responden memiliki tingkat penghasilan yang tidak adekuat (inadequate income). Hal ini menyebabkan pasien akan berusaha memenuhi kebutuhan yang menjadi prioritas atau kebutuhan dasar mereka saja, sehingga untuk mencapai nutrisi yang seimbang dan perawatan yang adekuat menjadi tidak maksimal.

Roselinda, dkk (2015: 75)

menyatakan bahwa Pekerjaan memiliki hubungan yang sangat kuat dengan perilaku berisiko tinggi untuk terinfeksi HIV/AIDS. Penularan HIV ke ibu rumah tangga (termasuk pengangguran) yang dianggap berisiko rendah, sebenarnya lebih tinggi transmisinya dari pada ke pekerja seksual. Hal ini dikarenakan ketidaksetaraan gender membuat wanita lebih sulit untuk mengontrol perilaku pasangan. Perilaku seksual dari orang-orang wiraswasta di atas dapat menjelaskan hubungan kerja dengan risiko tertular HIV-1 dan secara tidak langsung juga dengan subtipe CRF01_AE.

Peneliti berpendapat bahwa orang yang memiiki pekerjaan dengan ada penghasilan secara ekonomis kebutuhan dapat terpenuhi dibanding dengan orang yang tidak memiliki pekerjaan dan pengahasilan. Orang yang bekerja dapat dengan mudah untuk memenuhi kebutuhan hasrat seksual.

\section{Status Perkawinan}

Berdasarkan hasil menunjukkan bahwa sebagian besar status perkawinan responden menikah 18 orang $(60 \%)$. Sejalan dengan penelitian yang dilakukan oleh Laily (2013 dalam Kamilah \& Hastono, 2014: 15) menyatakan bahwa mereka yang sudah menikah memiliki ketergantungan secara biologis dan psikologis untuk melakukan aktivitas seksual secara rutin sehingga menyebabkan pasangan yang menikah/ kawin dapat memenuhi kebutuhan biologis pada pasangannya dibanding pada mereka yang tidak memiliki pasangan hidup. Namun, mereka yang tidak memiliki pasangan hidup akan lebih beresiko terjadi penularan HIV atau IMS lainnya dikarenakan kecendrungan berganti-ganti pasangan.

Hasil penelitian yang dilakukan oleh Ismiati dan Susmini 
(2018: 19) didapatkan bahwa terdapat hubungan antara status perkawinan dengan kejadian infeksi menular seksual wanita usia produkif di wilayah puskesmas Betungan Kota Bengkulu tahun 2017. Status perkawinan berperan dalam membentuk perilaku seksual seseorang. Status perkawinan memberi manfaat dalam membantu meningkatkan perilaku seksual yang aman dengan adanya anjuran dari pasangan agar memakai kondom saat berhubungan seks diluar pasangan tetap, terutama bila kedua belah pihak saling terbuka dalam negosiasi seks.

Hasil penelitian yang dilakukan oleh Sumini, dkk (2017: 41) Injecting drug users (IDU) status menikah berpeluang berisiko tertular virus HIV serta menularkan kepada pasangannnya karena perilaku penggunaan napza suntik, berbagi jarum dan perilaku jumlah pasangan seksual tidak tetap tanpa menggunakan kondom. IDU yang telah menikah ditemukan $89 \%$ aktif melakukan hubungan seksual dalam 6 bulan terakhir dengan istri/ pacar dan 95\% hubungan melalui vagina tanpa menggunakan kondom.

Peneliti berpendapat bahwa mereka yang sudah menikah memiliki ketergantungan secara biologis dan psikologis untuk melakukan aktivitas seksual secara rutin. Banyak faktor yang menyebabkan orang yang sudah menikah melakukan hubungan dengan diluar pasanganya, yaitu kurang harmonisnya hubungan seksual dengan pasangan, dampak dari istri sebagai wanita karier, gairah seksualtas pria yang lebih besar dibanding wanita, istri yang sedang masa nifas dan suami yang kerja jauh dari keluarga

\section{Analsis hubungan dukungan keluarga dengan tingkat kecemasan menghadapi kematian pasien ODHA}

Penelitian ini dilakukan dengan tujuan untuk mengetahui hubungan dukungan keluarga dengan tingkat kecemasan menghadapi kematian pasien ODHA (HIV/AIDS) di RSUD dr. Abdul Aziz Singkawang. Sampel penelitian ini sebanyak 30 orang.

Berdasarkan hasil hipotesa penelitian yang dapat dilihat dari tabel 5.5 didapatkan ada hubungan dukungan keluarga dengan tingkat kecemasan menghadapi kematian pasien ODHA di RSUD dr. Abdul Aziz Singkawang dengan nilai sig 0,048 .

Masalah fisik, psikologis dan sosisal yang dialami pasien HIV/ AIDS merupakan stresor yang dapat menyebabkan kecemasan. Kondisi fisik menurun dapat berpengaruh pada suasana hati, dan aktivitas lain. Hal ini sesuai dengan penelitian yang dilakukan oleh Chusna dan Nurhalina (2019: 99) yang mengemukakan bahwa terkait dengan state anxiety pada ODHA cenderung tidak stabil dan ketika ada kondisi tertentu dapat meningkatkan kecemasan. 
Selain diakibatkan masalah fisik, kecemasan dapat muncul dari banyaknya berita tentang kematian pasien ODHA. Kematian orang lain yang mengalami masalah yang sama akan menjadi faktor munculnya kecemasan akan kematian (Siregar \& Hardjo, 2017: 27). Hal senanda dikemukan oleh Hurlock (1996 dalam Siregar \& Hardjo, 2017: 28) bahwa kecemasan dapat berkaitan dengan datangnya kematian dan dapat juga berkaitan dengan caranya kematian serta rasa sakit atau siksaan yang menungkin menyertai datangnya kematian. Kecemasan kematian bisa menyerang siapa saja, umumnya kecemasan kematian merupakan suatu pikiran yang tidak menyenangkan, yang ditandai dengan kekhawatiran, rasa tidak tenang dan perasaan yang tidak baik atau tidak enak yang tidak dapat dihindari oleh seseorang. Untuk mengatasi masalah kecemasan yang dialami penderita ODHA diperlukan support system khususnya dukungan keluarga.

Menurut Friedman dalam Muhith dan Siyoto (2016 : 121) dukungan keluarga adalah sikap, tindakan dan penerimaan keluarga dalam dengan penderita yang sakit. Keluarga juga berfungsi sebagai sistem pendukung bagi anggotanya dan anggota keluarga memandang bahwa orang yang bersifat mendukung, selalu siap memberikan pertolongan dan bantuan jika diperlukan.

Hasil penelitian yang dilakukan oleh Ahdiany dkk (2017:
200) menyatakan bahwa terdapat perbedaan antara kecemasan secara umum dengan kecemasan terhadap kematian, yaitu objek dari rasa ketidaknyamanan tersebut dan dampak yang ditimbulkan. Kecemasan terhadap kematian adalah kondisi individu yang tidak menyenangkan meliputi gelisah, sulit tidur, bingung, was-was dan tidak nyaman akibat objek yang tidak jelas atau bahkan belum terjadi berupa peristiwa saat terlepas jiwa dan raga. Setiadarma dan Zamarlita (2008 dalam Ahdiany, 2017: 201) menyatakan bahwa kecemasan terhadap kematian muncul pada penderita penyakit kronis seiring dengan semakin melemahnya kondisi fisik, sosial dan psikologis penderta. Kecemasan terhadap kematian yang dirasakan ODHA membuat ODHA menjadi sangat sensitif seperti gemetar, panas dingin bahkan sampai kehilangan kesadaran, jika mendengar atau melihat berita tentang bencana, berita berduka dari kerabat ataupun hal-hal yang mendekati kematian.

$$
\text { Penelitian oleh Yasmin }
$$

(2017: 461) mendapatkan hasil bahwa ada hubungan negatif antara dukungan keluarga dengan kecemasan pada remaja HIV/ AIDS, artinya arah hubungan berlawanan sehingga semakin tinggi dukungan keluarga maka semakin rendah kecemasan remaja HIV/ AIDS. Ahdiany, dkk (2017: 206) menyatakan beberapa sumber penyebab kecemasan terhadap kematian yaitu pasien 
mencemaskan kematian mereka dan keluarga yang ditinggalkan juga merasakan cemas akan kematian anggota keluarganya yang sakit. Terlepas dari hal tersebut, kematian merupakan suatu proses yang hakiki yang akan dilewati oleh setiap orang, tidak mengenal usia, jenis kelamin, kondisi fisik ataupun latar belakangnya dan kematian itu sendiri akan datang pada waktu yang tidak kita ketahui.

Menurut Witty et al (1994, dalam Larasaty dkk, 2015: 122) menyatakan bahwa salah satu bentuk dukungan keluarga dalam upaya mengurangi kecemasan pasien ODHA yaitu orang tua atau keluarga berusaha menghibur dan memberi nasehat kepada pasien supaya tidak membebani diri dengan penyakit yang diderita. Keluarga perlu memahami fungsi pemeliharaan kesehatan, meliputi mengenal masalah kesehatan keluarga, memutuskan tindakan kesehatan yang tetap bagi keluarga, merawat keluarga yang mengalami gangguan kesehatan (salah satunya mengantar keluarga kunjungan/ kontrol ke fasilitas kesehatan), memodifikasi lingkungan keluarga dan memanfaatkan fasilitas kesehatan disekitarnya bagi keluarga.

Peneliti berpendapat bahwa kecemasan terhadap kematian merupakan suatu hal yang kompleks yang terjadi pada seseorang , berbagai macam pemikiran serta emosi mengenai kecemasan dan rasa takut untuk menghadapi kematian, kerusakan secara mental dan fisik, berbagai perasaan kesepian, kesedihan, keputus asaan yang mendalam pada situasi yang dihadapi ODHA yang tidak mampu di kontrol. Dengan adanya dukungan keluarga semua perasaan cemas dan situasi yang buruk dapat diminimalisir dan dapat memberikan rasa ketenangan selama hidup yang masih dijalani. Sesorang yang mampu memaknai hidupnya secara positif dapat meningkatkan penerimaan mereka terhadap kematian dan merasa bahwa kecemasan yang dirasakan akan diarahkah pada hal yang positif.

\section{KESIMPULAN}

Berdasarkan karakteristik responden bahwa dari 30 responden penderita ODHA sebagian besar yang berjenis kelamin laki-laki 18 orang $(60,0 \%)$, sebagian besar status pekerjaan karyawan swasta 14 orang $(46,7 \%)$ dan sebagian besar status perkawinan responden menikah 18 orang $(60 \%)$, ratarata berusia 35,27 tahun dan lamanya menderita ODHA rata-rata 7,37 tahun.

Sebagian besar responden yang memiliki dukungan keluarga yang buruk sebanyak 18 orang $(60,0 \%$. Sebagian responden yang memiliki tingkat kecemasan yang tinggi sebanyak 10 orang $(33,3 \%)$. Ada hubungan dukungan keluarga dengan tingkat kecemasan menghadapi kematian pasien ODHA di RSUD dr. Abdul Aziz Singkawang dengan nilai $p$-value $=0,048$. 


\section{UCAPAN TERIMA KASIH}

1. Ibu Fajar Yousriatin, M. Kes selaku Ketua STIKes YARSI Pontianak

2. Ibu Ns. Yunita Dwi Anggreini, M.Kep selaku ketua program studi Ners Keperawatan Stikes Yarsi Pontianak

3. Ibu Dr. Ns. Wahyu Kirana, M.Kep., Sp.Jiwa sebagai pembimbing I, yang telah memberikan masukan dan bimbingannya dalam penyusunan laporan penelitian ini.

4. Ibu Ns. Rara Anggreini, M.Kep.,Sp. Kep.J sebagai pembimbing II, yang telah memberikan masukan dan bimbingan dalam penyusunan laporan penelitian ini.

5. Seluruh staf dan dosen yang telah banyak membantu kelancaran penyelesaian laporan penelitian di STIKes Yarsi Pontianak.

6. Keluarga tercinta terutama bapak dan ibu saya yang telah banyak membantu baik secara materil, moril dan do'a untuk keberhasilan penulisan laporan penelitian ini.

7. Rekan-rekan yang namanya tidak dapat disebutkan satu persatu yang telah banyak membantu baik secara moril maupun spiritual sehingga laporan ini dapat diselesaikan.

\section{REFERENSI $\backslash$}

Ahdiany, G.N., Widianti, E., Fitria, N. 2017. Tingkat Kecemasan Terhadap Kematian pada ODHA. Jurnal Keperawatan Soedirman.12 (3): 199208.

Annisa, D.F., Ifdil, I., 2016. Konsep Kecemasan (Anxiety) pada Lanjut Usia (Lansia). Konselor 5, 93. https://doi.org/10.24036/02016526480 $\underline{-0-0}$
Ardhiyanti. 2015. Bahan Ajar AIDS pada Asuhan Kebidanan. Yogyakarta: CV. Budi Utama.

Chusna, Nurul and Nurhalina. 2019. Tingkat Kecemasan Ibu Rumah Tangga dengan HIV Positif di Kota Palangkaraya. 2, Palangkaraya : Jurnal Surya Medika , 2019, Vol. 4

Daly, M. 2015. Family and parenting support: policy and provision in a global context. UNICEF, Office of Research-Innocenti, Florence, Italy.

Dinkes Provinsi Kalimantan Barat. 2017. Profil Keesehatan Kota Pontianak Tahun 2017. Pontianak: Dinas Kesehatan.

Dharma, K.K., 2011. Metodologi Penelitian Keperawatan; Panduan Melaksanakan dan Menerapkan Hasil Penelitian. Trans Info Media, Jakarta.

Efendi, F., Mahkfudli. 2009. Keperawatan Kesehatan Komunitas; Teori dan Praktik dalam Keperawatan. Jakarta: Selemba Medika.

Ernawati., Sudarji, S., 2013. Kecemasan Mengahadapi Kematian pada Lanjut Usia.Jurnal Psikbernetika 6 (1), 28-38.

Friedman. 2013. Keperawatan Keluarga. Yogyakarta: Gosyen Publishing

Ibrahim, K., Kurnia, Y., Rahayuwati, L., Nurmalisa, B.E., Fitri, S.U.R. 2017. Hubungan antara Fatique, Jumlah CD4 dan Kadar Hemoglobin pada Pasien yang Terinfeksi Human Immunodeficiensy Virus (HIV). JKV. 5 (3): 271-280.

Irawati, D., Subandi., Kumoholohadi, R. 2011. Terapi Kognitif Perilaku Religius untuk Menurunkan Kecemasan terhadap Kematian pada Penderita HIV/ AIDS. Jurnal Intervensi Psikologi. 3 (2), 169-186.

Ismiati., Susmini. 2018. Hubungan Penggunaan Kondom dan Status 
Perkawinan dengan Kejadian Infeksi Menular Seksual pada Wanita Usia Produktif. Jurnal Ilmiah Bidan. 3 (2): 17-20.

Kemenkes, RI. 2015. Peraturan Menteri Kesehatan Republik Indonesia Nomor 87 Tahun 2014 tentang Pedoman Pengobatan Antiretroviral. Jakarta: Kementrian Kesehatan Republik Indonesia.

Lapau, B., 2013. Metode Penelitian Kesehatan: Metode Ilmiah Penulisan Skripsi, Tesis, dan Disertasi (Edisi Revisi). Jakarta: Yayasan Pustaka Obor Indonesia.

Larasaty, Nurina Dyah, Shaluhiyah, Zahroh and Suryoputro, Antono. 2015. Bentuk-Bentuk Dukungan Keluarga Terhadap Ibu dengan HIV Positif. 2, Semarang : Jurnal Promosi Kesehatan Indonesia, 2015, Vol. 10.

Madyan, Ahmad Shams. 2009. Aids dalam Islam: Krisis Moral atau Krisis Kemanusiaan? Bandung : Mizan Pustaka, 2009. 979433541X, 9789794335413.

Muhith, Abdul and Siyoto, Sandu. 2016. Pendidikan Keperawatan Gerontik. Yogyakarta : ANDI, 2016. $9792962018,9789792962017$.

Murni, S., Green, C.W., Djauzi, S., Setiyanto, A., Okta, S., 2015. Lembar Informasi tentang HIV/ AIDS untk Orang Yang Hidup dengan HIV (Odha). Yogyakarta: Yayasan Spiritia. 979-97494-0-9.

Kambu, Y., Waluyo, A., Kuntarti. Umur Orang HIV/ AIDS (ODHA) berhubungan dengan Pencegahan Penularan HIV. Jurnal Keperawatan Indonesia. 19 (3): 200-207.
Kamilah, E.M., Hastono, S.P. 2014. Hubunga Karakteristik Pasien, Perilaku Behavior dan Infeksi Manular Seksual dengan Kejadian HIV/ AIDS di Klinik VCT (Voluntary Counselling and Testing) Puskesmas Cikarang Kecamatan Cikarang Utara Kabupaten Bekasi Tahun 2013. FKM UI: 4-20.

Kemenkes RI. 2014. Situasi dan Analisis HIV AIDS. Jakarta: Direktorat Jendral Pengendalian Penyakit dan Penyehat Lingkungan Departemen Kesehatan Republik Indonesia.

Kemenkes RI. 2018. Laporan Perkembangan HIV-AIDS \& Infeksi Menular Seksual (IMS) Triwulan I V tahun 2017. Jakarta: Direktorat Jendral Pengendalian Penyakit dan Penyehat Lingkungan Departemen Kesehatan Republik Indonesia.

Luthfiana, Y. 2012. Hubungan Pengetahuan dan Sikap terhadap Perilaku Berisiko HIV/ AIDS pada Pekerja Bangunan Proyek World Class University Tahun 2012. Jakarta: Universitas ndonesia. Diakses 31 Juli 2019.

Mardjan, 2016. Pengaruh Kecemasan pada Kehamilan Primipara Remaja. Abrori Institute, Pontianak.

McKitterick, S., 2015. Everyone experiences anxiety. NAMI Arlington

Mind, 2015. Understanding Anxiety and Panic Attacks; Mind for Better Mental Health.

Muhith, A., \& Siyoto, S. (2016). Pendidikan Keperawatan Gerontik. Yogyakarta: ANDI.

Nursalam. 2015. Metodologi Penelitian Ilmu Keperawatan Pendekatan Practis 
Edisi 4. Jakarta : Selemba Medika, 2015. 978-602-1163-38-2.

O’Brien, P.G., Kennedy, W.Z., Balard, K.A., 2014. Keperawatan Kesehatan Jiwa Psikiatrik; Teori \& Praktik. Jakarta: EGC.

Potter, P.A. 2005. Buku Ajar Fundamental Keperawatan: Konsep, Proses dan Praktik, Vol 1, Edisi 4. Jakarta: EGC.

Rahakbauw, Nancy. 2016. Dukungan Keluarga terhadap Kelangsungan Hidup ODHA (Orang dengan HIV/ AIDS).2, s.1.: Insani, 2016, Vol. 3. ISSN : 2407-6856.

Rachmawati, S. (2013). Kualitas Hidup Orang dengan HIV/AIDS yang Mengikuti Terapi Antiretroviral. Jurnal Sains dan Praktik Psikologi, 1 (1), $48-62$.

Rector, dkk. 2011. Anxiety Disorders an Information Guide. Centre for Addiction and Mental Health Centre de Toxicominie et de Sente Mentele (CAMH): Canada.

Roselinda., Wibowo, H. A., Setiawaty. 2015. Karakteristik Pekerjaan pada Kasus Human Immunodeficiency Virus-1 dan Subtipenya di Tujuh Provinsi di Indonesia pada tahun 2011. Jurnal Biotek Medisiana Indonesia. 4 (2): 71-76.

Sarwono, J., 2011. Mixed Methods; Cara Menggabung Riset Kuantitatif dan Riset Kualitatif Secara Benar. Jakarta: PT Elex Media Komputind.

Siregar, I.M., Hardjo, S. (2017). Hubungan Kecemasan Kematian dan Dukungan
Sosial terhadap Motivasi Kerja Karyawan ODHA (Orang dengan HIV-AIDS). Journal Keperawatan Indonesia; 26-33. Issn: 2085-6601.

Struart, G.W. 2016. Principles and Practice of Psychiatric Nursing. (10 th Ed). Elsevier: Mosby.

Sudarma, Momon. 2008. Sosiologi untuk Kesehatan. Jakarta: Selemba Medika.

Sumini., Hadisaputro, S., Anies., Laksono, B., Sofro, M.A. 2017. Faktor Risiko yang Berpengaruh terhadap Kejadian HIV/AIDS pada Pengguna Napza Suntik (Studi Epidemiologi Di Kota Pontianak). Jurnal Epidemiologi Kesehatan Komunitas. 2 (1): 36-45.

Summit, 2015. family Support Research and Outcome. School of Social Work,University of North Carolina at Chapel Hill.

Swarjana, K., 2015. Metodologi Penelitian Kesehatan: Tuntunan Praktis Pembuatan Proposal Penelitian untuk Mahasiswa Keperawatan, Kebidanan dan Profesi Bidang Kesehatan. ANDI, Yogyakarta.

Umam, H., Dewi, Y.I., Elita, V. 2015. Identifikasi Karakteristik Orang Resiko Tinggi HIV dan AIDS tentang Program Pelayanan Voluntary Counselling Testing (VCT). Jom. 2 (1): 853-862.

UNAIDS. 2018. Data 2018. Switzerland: United Nations Programme on HIV/ AIDS.

Videbeck, S.L. 2012. Buku Ajar Keperawatan Jiwa (Psychiatric Mental Health Nursing). Jakarta: EGC. 